\title{
Investigating the structure of the Milun Fault from surface ruptures of the 2018 Hualien Earthquake
}

\author{
Yi-Chun Hsu ${ }^{1, *}$, Chung-Pai Chang ${ }^{1,3}$, Jiun-Yee Yen ${ }^{2}$, Hao Kuo-Chen ${ }^{1,4}$, and Chun-Chin Wang ${ }^{1}$ \\ ${ }^{1}$ Department of Earth Sciences, National Central University, Taoyuan City, Taiwan \\ ${ }^{2}$ Department of Natural Resources and Environmental Studies, National Dong Hwa University, Hualien County, Taiwan \\ ${ }^{3}$ Center for Space and Remote Sensing Research, National Central University, Taoyuan City, Taiwan \\ ${ }^{4}$ Earthquake-Disaster \& Risk Evaluation and Management Center (E-DREaM), National Central University, Taoyuan City, \\ Taiwan
}

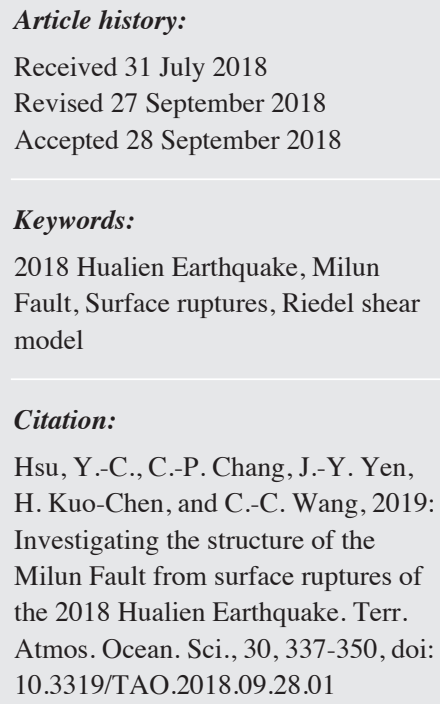

\begin{abstract}
A deadly $\mathrm{M}_{\mathrm{w}} 6.4$ earthquake occurred in the Hualien area of eastern Taiwan on 6 February 2018. It caused severe damage to infrastructure and creating surface ruptures in several areas mostly near the Milun Fault in Hualien City. In this study, we investigated the distribution of co-seismic surface ruptures by measuring the orientations of the ruptures, classifying the fracture patterns, and measuring the fracture geometries to calculate the principal displacement zone (PDZ) and the regional stress directions. As a result, local PDZ is observed to rotate anti-clockwise along the Milun Fault from north to south. Considering the deformation behaviors of the fractures and their relative positions along the Milun Fault, the shear zone in Qixingtan area is a horsetail structure derived from the right side of the end of the left-lateral strike-slip fault. In addition, the $170^{\circ}$ trending fault splay in the middle segment and the fault branch corresponding to the Beipu Fault are elements of the Riedel shear structure associated with the left-lateral moving Milun Fault. Our results show that Riedel shear structures are common within co-seismic surface rupture zones in this area, and the variations in the orientations of Riedel structures reflect the influence of the pre-existing Milun Fault. We can also determine the most recent geometry, kinematics, and displacement characteristics of the Milun Fault through co-seismic surface ruptures and macro-scale Riedel shear structure analysis. This study provides a good example of understanding the relationship between the outcrop scale and the macroscale of the Riedel shear model.
\end{abstract}

\section{INTRODUCTION}

The $\mathrm{M}_{\mathrm{w}} 6.4$ Hualien Earthquake occurred on 6 February 2018, along the northeastern offshore of Hualien City at 6.3-km depth (Fig. 1). Maximum shaking intensity of 7 is observed in Hualien City and the Nanao area in Ilan City. According to the seismic moment tensor solution and the distribution of aftershocks (according to Central Weather Bureau, hereby CWB), this earthquake is dominated by strike-slip motion along on a fault striking NE-SW and dipping to NW, with the compression axis oriented along NNW-SSE (Fig. 1; data from CWB's February earthquake catalog). From the map view, this mainshock is barely linked

\footnotetext{
* Corresponding author

E-mail:jiijiun@gmail.com
}

to any known active faults on the surface. However, it may be related to a shallow structure located in the offshore area.

In most cases, shallow large earthquakes result in surface ruptures related to their corresponding active fault systems. However, many previous studies have shown that occasionally, co-seismic deformation and surface ruptures not only reflect the surface trace of the fault, but also provide an indication of the structural characteristics of the fault in depth, in addition to being related to a pre-existing tectonic environment (e.g., King 1986; Lin et al. 2001, 2003, 2009a, 2011). In this study, despite the unknown offshore seismogenic structure, we observe surface ruptures onshore. We propose that the surface ruptures associated with the 2018 Hualien Earthquake could be affected by the pre-existing active fault - the Milun Fault - the geometry of which is not compatible with 
that of the main shock. This study is a good opportunity to observe the effects of the stress generated by earthquakes on pre-existing structures, and the degree of influence of preexisting structures on co-seismic surface ruptures.

Another focus of this study is the outcrop-scale coseismic structural features. From field investigations, the distribution of the surface rupture areas is mostly located along the Milun Fault and the northernmost part of the Lingding Fault (Fig. 2c). Most of the co-seismic surface ruptures occurred on artificial infrastructure (e.g., asphalt layer). Among them, we can identify the conjugate Riedel shear structures caused by the left-lateral strike-slip movement of the Milun Fault (Hsu et al. 2018). The 2018 Hualien Earthquake provides a good opportunity to study the forming mechanism and kinematics of co-seismic Riedel shear structures, to further investigate the rupturing behavior based on the mechanical properties of the Milun Fault, as well as clarifying the geometry, kinematics, and displacement characteristics of the Milun Fault.

\section{TECTONIC SETTING}

The 2018 Hualien Earthquake occurred at the junction of the plate boundary between the Philippine Sea plate and the Eurasian plate. The Philippine Sea plate subducts towards the northwest beneath the Eurasian plate along the Ryukyu trench, while the coastal range on the Philippine Sea plate collides with the Eurasian plate along the Longitudinal Valley (Fig. 2a). Hualien City is located at the transition zone between the subduction and the collision (Chen et al. 2014a). This zone is one of the most seismically active regions in Taiwan. GPS observations show the velocity field changes from the northwest direction in the Longitudinal Valley to the north in Hualien City (Fig. 2b; Yu et al. 1997; Chen et al. 2014a). The focal mechanism solutions of background seismicity indicate that the compression axis along the northwest-southeast direction changes to northeast-southwest in this area (Fig. 2b; Wu et al. 2009). These results show that the stress field of the main shock area is very complicated.

The distribution of aftershocks ranges from the northeastern offshore of Hualien City to the south of Hualien City, on either side of the Milun Fault, with the aftershock sequence further extending southward to the northernmost segment of the Longitudinal Valley, also called the Lingding Fault (Yu and Kuo 2001; Chen et al. 2007; Fig. 1). The co-seismic surface ruptures are mainly distributed on both sides of Milun Fault and Lingding Fault (Fig. 2c). This area is mostly covered by Quaternary alluvial deposits and terraces (Lin 1962; Chung et al. 2004; Lin et al. 2009b). The Milun Tableland, located to the east of the Milun Fault, is mainly composed of Milun Conglomerate, overlain by the Middle Pleistocene Milun Formation in the north and south Milun terraces. Ancient Meilun River alluvial sediments and ancient Meilun lake sediments (Hualien Formation) between the terraces (Milun Formation) are the youngest sediments in the Milun Tableland. The Milunshan conglomerate is distributed in the Meilun Hill and consists of gravel and sand (Fig. 2d; Lin 1962; Chung et al. 2004; Lin et al. 2009b).

The northernmost end of Milun Fault can be traced from the Qixingtan coast (Fig. 2b). The fault trace closely follows the western edge of the Milun Tableland with a northeastern strike, further extending southwards into the Hualien City (Chung et al. 2004; Chang et al. 2014a, b). The surface of the Milun Fault is approximately $8 \mathrm{~km}$ long. It is a left-lateral strike-slip active fault with reverse component (Hsu 1955, Fig. 2d). According to the shallow reflection seismic data, the Milun Fault is steeply east-dipping (Liau 2006). Previous research shows that the activity in the Milun Fault was intermittent. When a large earthquake occurs, the hanging wall of the Milun Fault uplifts violently with a significant horizontal displacement (Lu 2009; Yen et al. 2011). This fault historically ruptured during the 1951 Hualien Earthquake ( $\mathrm{M}_{\mathrm{L}}$ 7.3), revealing co-seismic deformation with an offset of 1.2 and $2 \mathrm{~m}$ for its vertical and left-lateral strike-slip components, respectively (Tang 1952; Hsu 1955, 1962; Lin 1962; Yu et al. 1997). The study of an elastic dislocation model from the GPS data (Yu et al. 1990) suggested that the Milun Fault had a significant left-lateral and reverse slip during the 1986 Hualien earthquake $\left(M_{L} 6.8\right)$. During the interseismic period, the Milun Fault slipped sinistrally at a rate of $3-8 \mathrm{~mm} \mathrm{y}^{-1}$, while the central-southern segment $\left(5-8 \mathrm{~mm} \mathrm{y}^{-1}\right)$ moves slightly more rapidly than the northern segment $\left(3 \mathrm{~mm} \mathrm{y}^{-1}\right)$ (Chen et al. 2014a). The uplift rate of the hanging wall is generally very low $\left(1 \mathrm{~mm} \mathrm{y}^{-1}\right.$, Chen et al. 2014b).

In addition, there are two minor faults, the Beipu Fault and the Mingyi Fault, related to the Milun Fault. The Beipu Fault is located on the northwest side of Hualien City. The length of this fault is approximately $2.3 \mathrm{~km}$. The terrain on the western side of Beipu Fault is slightly tilted towards the northeast, while the Meilun River along the fault developed abnormal geomorphic features (Fig. 2b), which is believed to be related to the long-term movement of the Beipu Fault (Shih et al. 1983). According to the results of the PSInSAR analysis from Envisat radar images, the Beipu Fault showed intermittent activity from 2004 to 2008. An uplift event occurred on the east side of the Beipu Fault, which can be related to the 2005 earthquake events. The relative maximum displacement reaches approximately $16 \mathrm{~mm}$ (Chang et al. 2006; Yen et al. 2006, 2011).

The Mingyi Fault is located approximately $1 \mathrm{~km}$ east of the Milun Fault, and is proposed as a west-dipping reverse fault with a left-lateral strike-slip component (Yang 1986; Yu 1994; Lin and Hsiao 1998). The PSInSAR result indicates that the Mingyi Fault actively deformed from 2004 to 2008. However, the deformation of this fault was not clear to the south of the Milun Tableland (Yen et al. 2011; Kao 2016). 

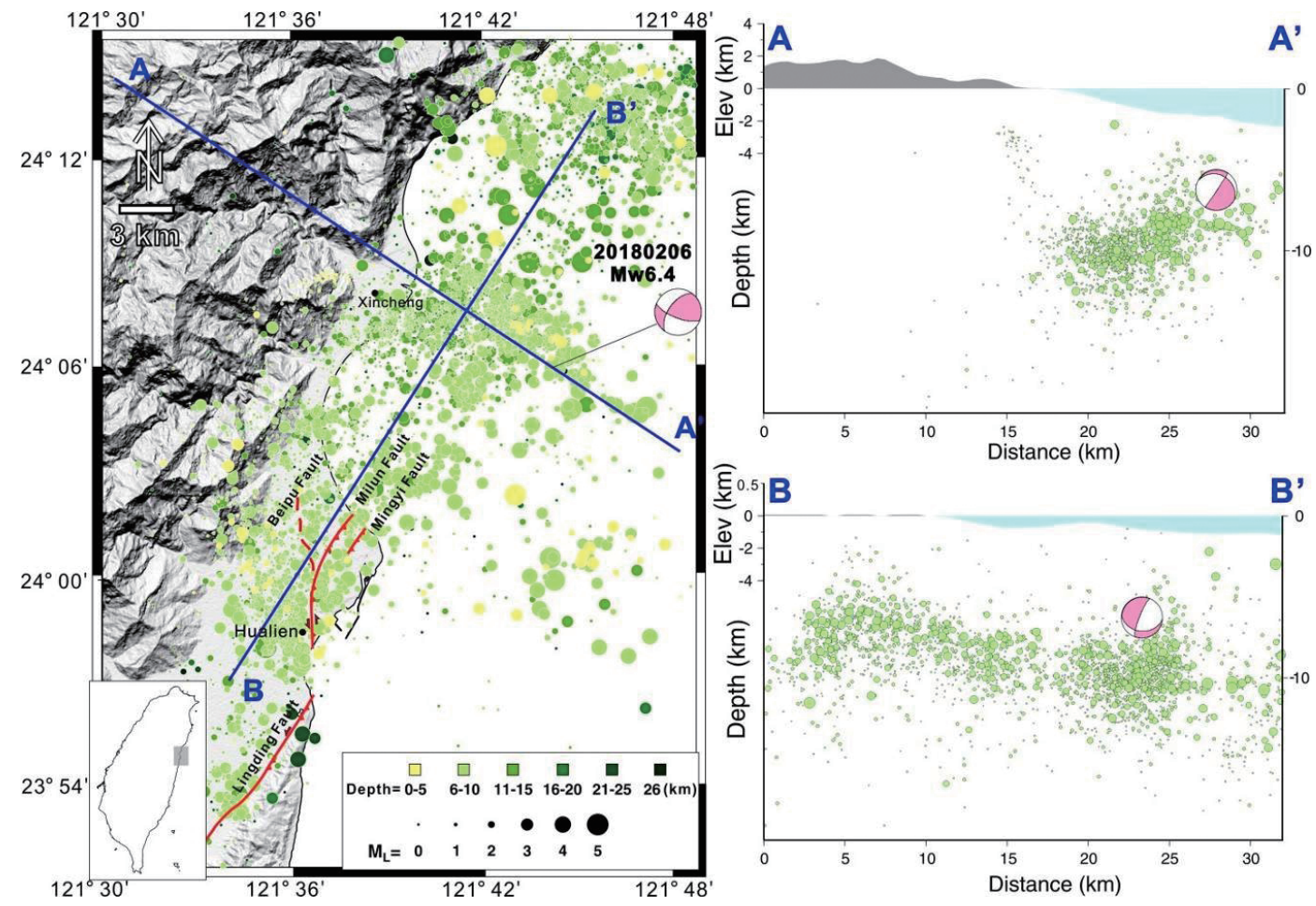

Fig. 1. Maps of 2018 Hualien Earthquake sequence and aftershocks (data from the February earthquake catalog of Central Weather Bureau).
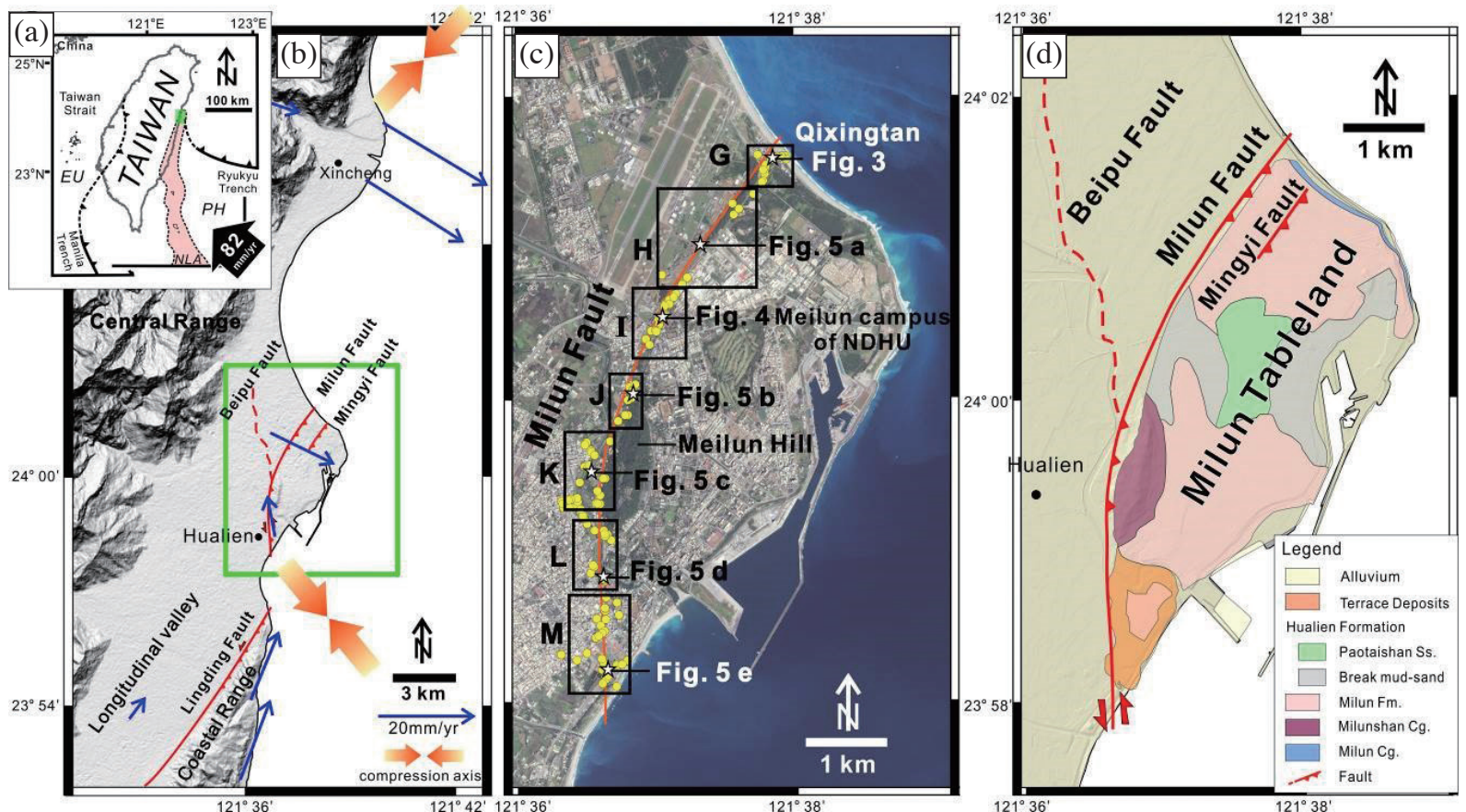

Fig. 2. (a) Tectonic setting. (b) Topography and GPS velocity vectors (in the ITRF2000 frame) of Hualien City area. The GPS vectors marked by blue arrows, data from GPSLab of Academia Sinica (data: 1993.01.01-2018.08.31; http://gps.earth.sinica.edu.tw). The orange arrows show P axis (compression axis) from the focal mechanism of the background earthquake (Wu et al. 2009). The green box is a study area. (c) Map of the co-seismic rupture location. The background is a SPOT7 satellite image (AIRBUS DC/CSRSR 2018). The yellow point in the figure is the surface rupture position caused by the 2018 Hualien Earthquake, indicating that most of the ruptures are located near the Milun Fault. According to the geometry and distribution characteristics of the fracture, the line can be divided into seven investigation areas (G - M). (d) Geological map of the study area (modified from the Milun Fault zone geological map, Lin et al. 2009b). 


\section{ANALYTICAL METHODS}

\subsection{Investigation of the Co-seismic Surface Ruptures}

The co-seismic surface ruptures of the 2018 Hualien Earthquake are mainly distributed along the pre-existing active fault, the Milun Fault. Moreover, the structural characteristics of the Milun Fault control the destitution and the amount of co-seismic surface ruptures (Fig. 2c). The coseismic surface ruptures can be divided into seven segments (Fig. 2c, G - M) from the northeast to the south, based on the structural features and distribution patterns. From the field observations, the fracture patterns along the Milun
Fault show the conjugate shear fractures, en echelon tension cracks, tension fractures, and compression textures.

At the northern end of the Milun Fault, Qixingtan area had the maximum surface deformation (G segment in Figs. 2c, 3). The Qixingtan Bridge is severely damaged, and the distribution of the surface ruptures extended from the Qixingtan Bridge, across the Qixing Street to the Qixingtan Coast (Fig. 3a). We can observe several left-lateral strike-slip displacements and compression textures (site G1, Fig. 3b). Qixing Street (site G2, G3) is dominated by strong transpressional and ENE-WSW-trending compression textures with a $63-\mathrm{cm}$ shortening and a $25-\mathrm{cm}$ left-lateral
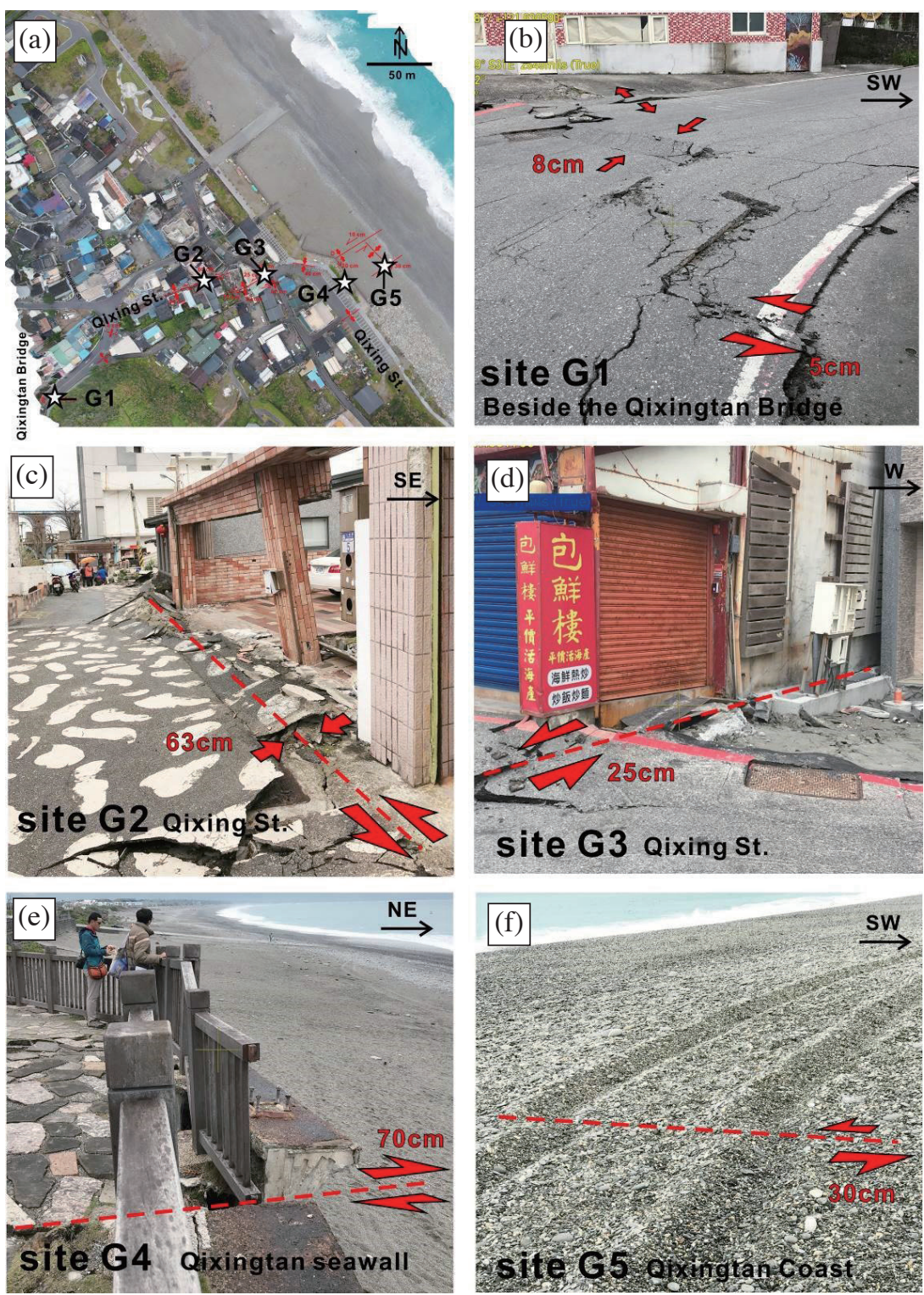

Fig. 3. Surface ruptures in Qixingtan area (the location is shown in Fig. 2c). (a) SPOT7 image of the Qixingtan area (AIRBUS DC/CSRSR 2018). The star mark in the image indicates the photo positions of (b), (c), (d), (e), and (f), respectively. (b) Left-lateral strike-slip offset and compression texture on Qixing Street. (c) Compression texture in front of the houses on Qixing Street. (d) Transpression caused by pavement and house destruction on Qixing Street. (e) On the Qixingtan Coast, there is a $70 \mathrm{~cm}$ right-lateral offset of the seawall. (f) A 20-cm offset of the traces of the car on the beach is dominated by a left-lateral strike-slip displacement. 
displacement (Figs. 3c, d). On the Qixingtan Coast, there is a 70-cm right-lateral offset of the seawall (site G4, Fig. 3e). A $20-\mathrm{cm}$ offset of the traces of the car on the beach is dominated by a left-lateral strike-slip displacement with a NE-SW orientation (site G5, Fig. 3f).

The Meilun campus of the National Dong Hwa University (NDHU) is approximately $1.5 \mathrm{~km}$ southwest of Qixingtan on the western side of Milun Tableland near the Milun Fault, with NE-SW to N-S orientation (I segment in Fig. 2c). The Milun Fault passes through the campus. Several buildings and the artificial surface of the campus were damaged due to this earthquake. The representative rupture is a series of compressed ridges and left-lateral strike-slip structures with a maximum shear of $20 \mathrm{~cm}$ along Fuqian road near the SW side door of the school (site I1, Fig. 4b) and the square in front of the stadium (site I2, Fig. 4c). The trend of the shear zone is approximately N-S. The polyurethane material above the track field formed a series of en echelon tension cracks, and the trend of the left-stepping crack is N-S with a $15-\mathrm{cm}$ shearing ( site I3, Fig. 4d). In addition, we can observe left-lateral and right-lateral strike-slip features in front of the school gate (site I4, Fig. 4e) and the garden with the Confucius statue (site I5, Fig. 4f). The right-lateral displacement of the garden is approximately NW-SE, while the offset is $6.5 \mathrm{~cm}$ (Fig. 4f).

The surface ruptures in other regions are more decentralized and caused some damage to roads. In the northern
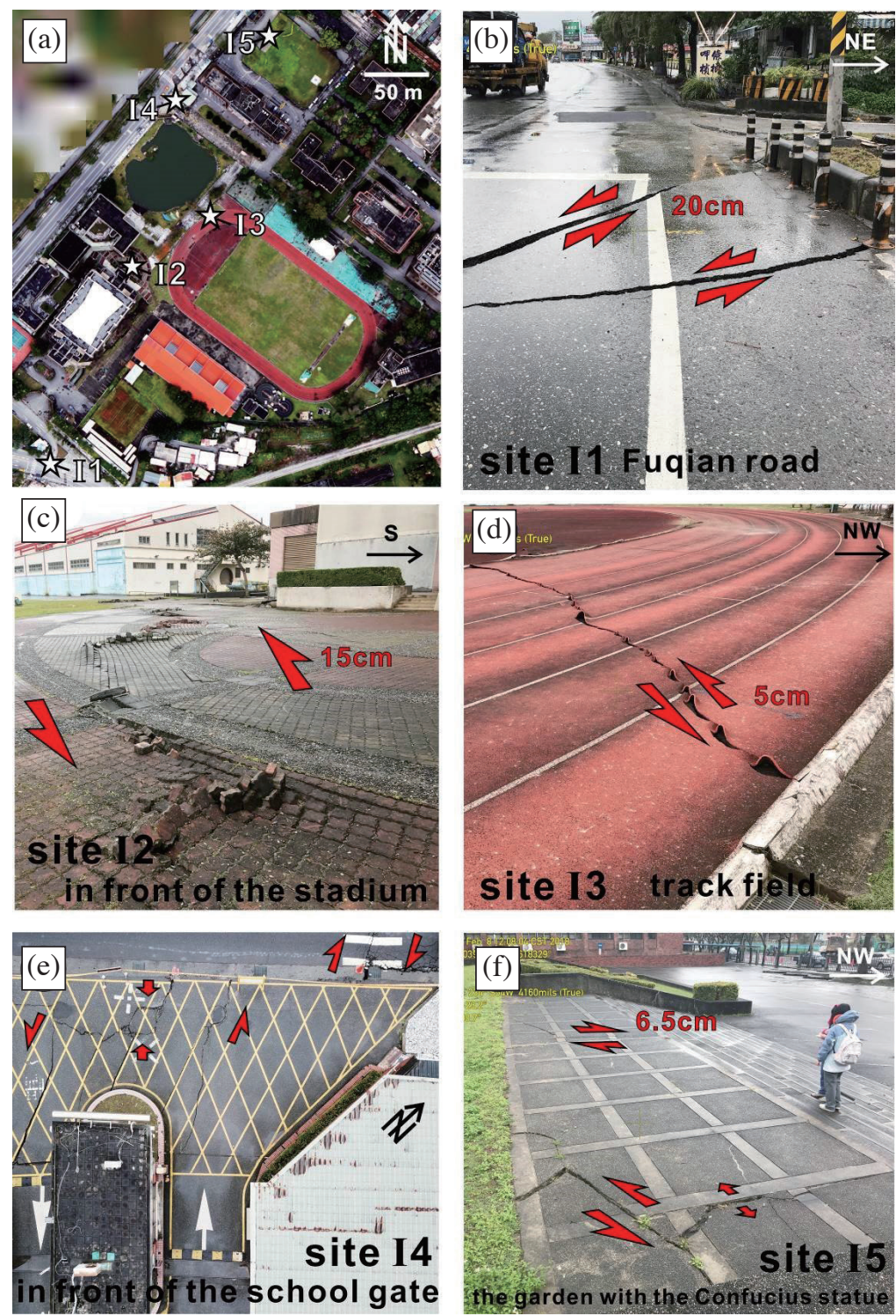

Fig. 4. Surface rupture in the Meilun campus of NDHU (the location is shown in Fig. 2c). (a) SPOT7 image of the Meilun campus of the NDHU (AIRBUS DC/CSRSR 2018). The star mark in the image indicates the photo positions of (b), (c), (d), (e), and (f), respectively. (b) Left-lateral strikeslip offset at Fuqian Road. (c) A series of transpression cracks at the square in front of the stadium. (d) Left-lateral strike-slip offset at a track field. (e) An air photo is taken at the gate. The shearing situation can be observed through the misalignment of the marking. (f) Left-lateral and right-lateral strike-slip features in front of the school gate and the garden with Confucius statue. 
part of the Milun Fault (Huaxi Road), the NNE-SSWtrending co-seismic surface ruptures were dominated by left-lateral strike-slip, with a 70 -cm displacement (in $\mathrm{H}$ segment, Fig. 5a). On the Xingxing Road on the northern side of the Meilun Hill, a compressed ridge is produced with a left-lateral component and a shortening of $24 \mathrm{~cm}$ (in $\mathrm{J}$ segment, Fig. 5b). In the southern part of the Milun Fault, the most common kind of rupture on the road is compression textures. The NE-SW-trending compression ridge can be observed at the intersection of Guosheng $4^{\text {th }}$ Street and Shangzhi Road (in K segment, Fig. 5c), Mingli Elementary School (in L segment, Fig. 5d), and Mingyi Road (in M segment, Fig. 5e). The maximum shortening is approximately $21 \mathrm{~cm}$ (Fig. 5d).

\subsection{Riedel Shear Structure Analysis}

After investigating the distribution of co-seismic sur- face ruptures, measuring the orientation of the ruptures, and distinguishing the fracture patterns, we correlated the fracture geometries to the Riedel shear structures in order to determine the principal shear zone directions and the regional stress field. The Riedel shear structures were first reported by Riedel (1929). In previous studies, they have been widely used at various scales of strike-slip faults, such as map scales, outcrops, or microscales (e.g., Bestmann et al. 2000; Davis et al. 2000; Ahlgren 2001; Lin et al. 2001; Angelier and Bergerat 2002; Katz et al. 2004; Scholz et al. 2010; Zhang et al. 2010). Geometrically, the Riedel shear structures are characterized by a series of fracture structures, including $R$ and $\mathrm{R}$ ' conjugate shear fractures, compression textures, tension fractures, and P structure (Fig. 6a). The patterns of these fracture structures have a specific angular relationship with the principal displacement zone (PDZ): idealized conjugate $\mathrm{R}$ and $\mathrm{R}^{\prime}$ structure inclined at angles of $\Phi / 2$ and $90^{\circ}-\Phi / 2$ to the general trend of the PDZ, where $\Phi$ is the angle of
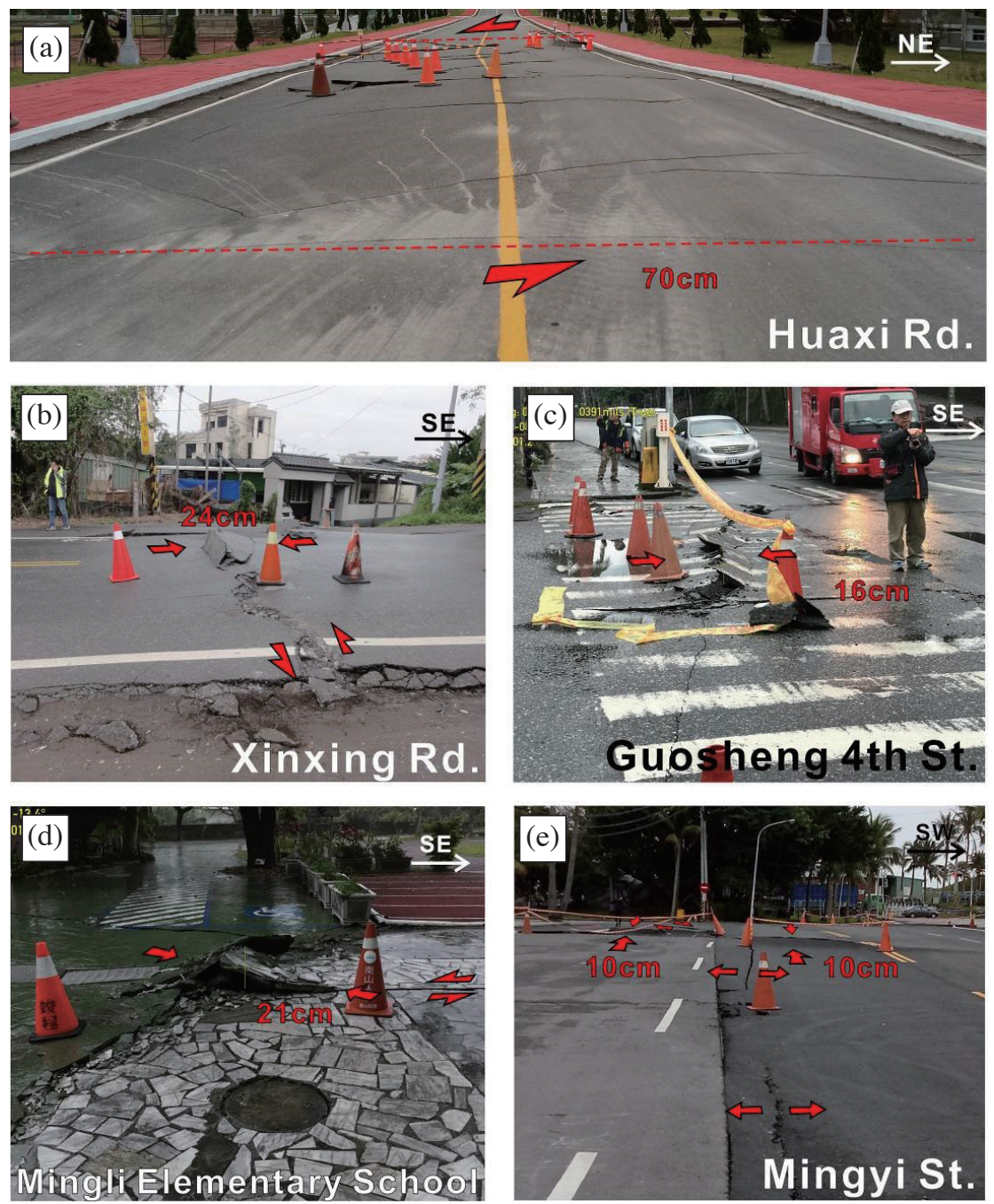

Fig. 5. Surface ruptures along the Milun Fault (photograph location is shown in Fig. 2c). (a) Left-lateral strike-slip offset near the Huaxi Road. (b) Left-lateral strike-slip offset and compression texture at Xingxing Road. (c) Compression texture at the intersection of Guosheng $4^{\text {th }}$ Street and Shangzhi Road. (d) Compression texture in Mingli Elementary School. (e) Tension feature and compression texture at Mingyi Street. 

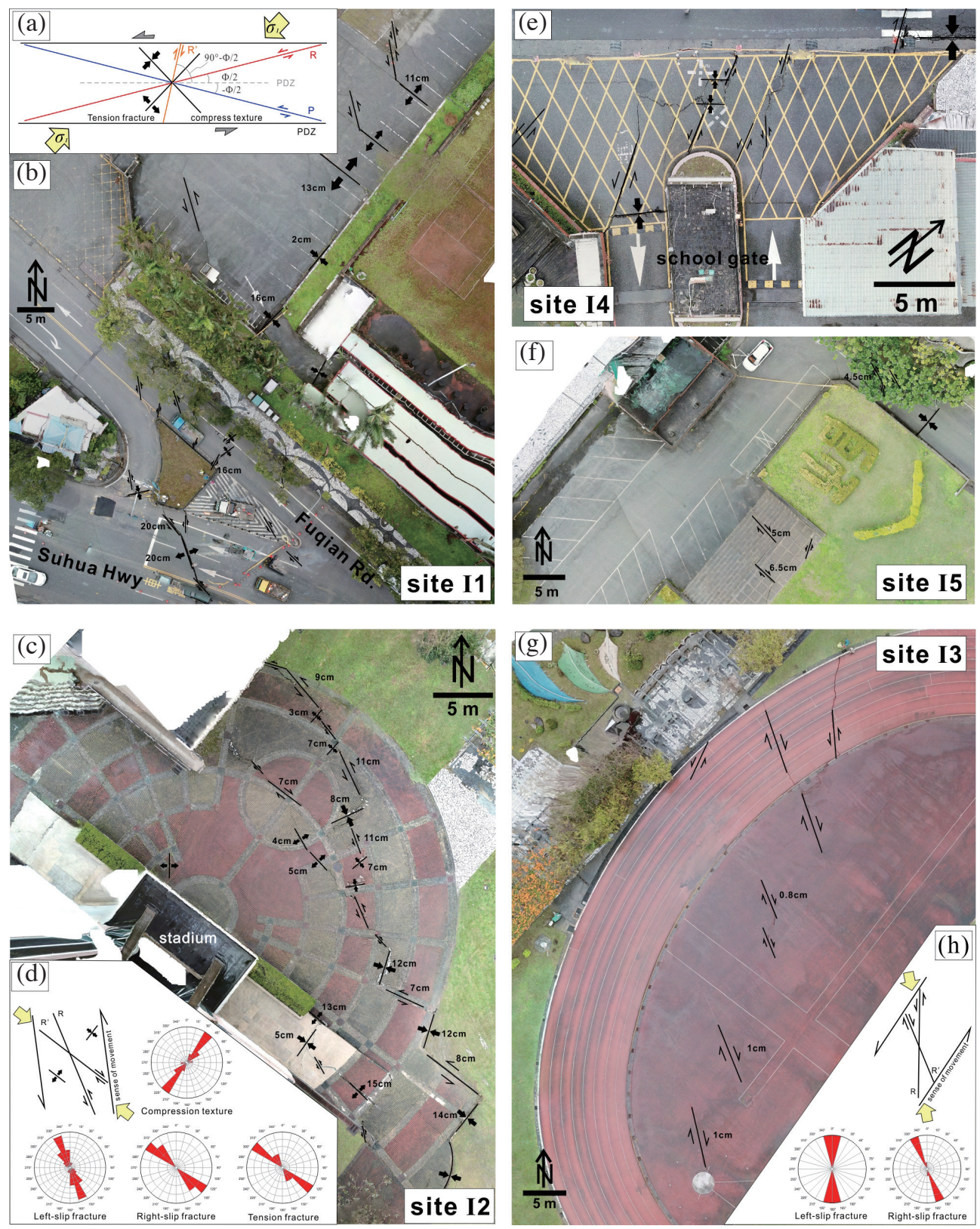

Fig. 6. Fracture pattern of the co-seismic surface ruptures in the shear zone in the Meilun campus of NDHU. (a) Schematic diagram of a shear zone. (b) Surface rupture pattern on Fuqian road near the side door of the school. (c) Surface rupture pattern in front of the stadium. (d) Redial shear analysis results for the Meilun campus of the NDHU [results from (b), (c), (e), (f), and except the track field]. (e) Surface rupture pattern at the school gate. (f) Surface rupture pattern in front of the school gate and the garden with Confucius statue. (g) Surface rupture pattern on the track field. (h) Redial shear analysis results of the track field (site I3). 
internal friction of the host rock (Fig. 6a; Tchalenko 1968, 1970; Bartlett et al. 1981; Davis et al. 2000; Ahlgren 2001). Both the compression textures and tension fracture are at an angle of approximately $45^{\circ}$ to the PDZ, while being perpendicular to each other. The $\mathrm{R}$ and $\mathrm{P}$ structure are synthetic to the sense of slip along the principal shear zone, while the R' structure is antithetic (Fig. 6a).

Taking the Meilun campus of NDHU as an example, the fractures near the SW side door of the school (site I1, Fig. 6b), in front of the stadium and the school gate (site I2, I4, Figs. 6c, e), and the garden with the Confucius statue (site I5, Fig. 6f) include the left-lateral and the right-lateral shear fractures, tension fractures, and compression textures. We counted the azimuths of various ruptures in these areas. The left-lateral shear fractures ( $\mathrm{R}$ structure) were generally NNW-SSE-trending, the right-lateral shear fractures ( ${ }^{\prime}$ ' structure) were generally NW-SE-trending, the compression textures were oriented towards mean NE-SW, and the tension fractures were oriented towards mean NW-SE. These results indicate that the azimuth of the local PDZ is approximately $\mathrm{N}-\mathrm{S}$ trending (azimuth $170^{\circ}$ ), while the direction of the maximum horizontal compress stress $\left(\sigma_{\mathrm{H} \max }\right)$ is NW-SE trending (Fig. 6d). The surface rupture pattern on the track field is different from other places in the Meilun campus of NDHU (Fig. 6g). The left-lateral shear fractures (R structure) were generally $\mathrm{N}$-S-trending, while the right-lateral shear fractures ( $\mathrm{R}^{\prime}$ structure) were generally NNW-SSEtrending. According to the statistical results, the orientation of the local PDZ is NE-SW trending (Fig. 6h).

According to the survey results, a total of 270 surface ruptures were located in the study area. After deducting the surface rupture of human factors, we measured a total of 200 data for analysis. By using the Riedel shear structure analysis method, the local PDZ and the maximum horizontal compress stress $\left(\sigma_{\text {Hmax }}\right)$ direction of each segment ( $\mathrm{G}$ - M block) are shown in Fig. 7. This result shows that the local PDZ rotates anti-clockwise along the Milun Fault from north to south. In the Qixingtan area, the local PDZ is approximately E-W trending (azimuth $80^{\circ}$ ). However, it gradually turned NE-SW trending (azimuth $25^{\circ}$ ) towards the west. To the east of the Meilun campus of NDHU, the local PDZ is NE-SW trending (azimuth $30^{\circ}$; Fig. 7, I-1), which changes to the N-S direction south of the Meilun Hill area (azimuth $5^{\circ}$; Fig. 7 , $\mathrm{J}, \mathrm{L}, \mathrm{M})$. In addition, we can observe the fault branches with an azimuth of $170^{\circ}$ in the Meilun campus of NDHU (Fig. 7, I-2) and the central part of Meilun Hill (Fig. 7, K). With the

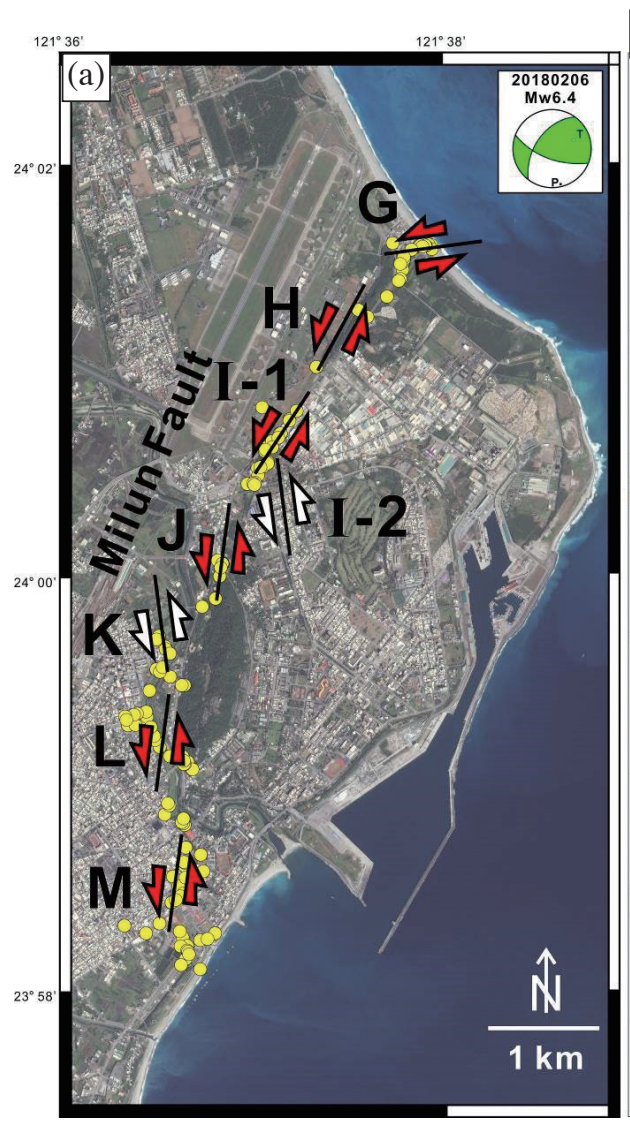

(b)

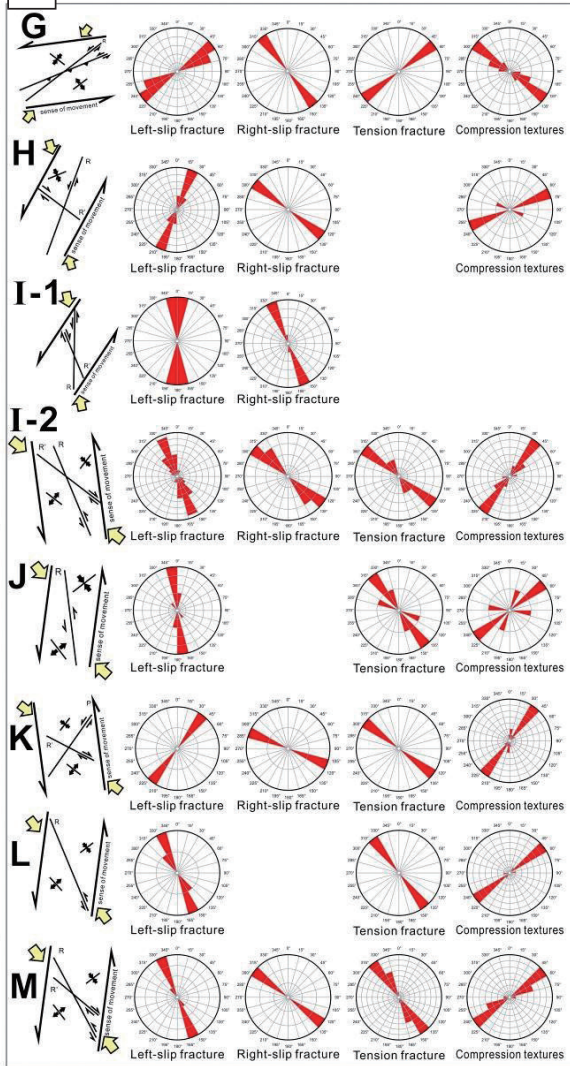

Fig. 7. (a) Analysis diagram of the local principal shear direction and the shear sense. The yellow point in the figure is the surface rupture position caused by the 2018 Hualien Earthquake. (b) Rose diagrams showing the distribution of angles between individual rupture strands and the Riedel shear model in $\mathrm{G}$ - M segments. 
Meilun campus of NDHU as the boundary, the shearing and shortening in the northern section is larger than that in the southern section, while the rupture distribution is relatively divergent in the southern section.

\section{DISCUSSION}

\subsection{Riedel Shear Structure of the Surface Ruptures}

During the development process of Riedel shear structure in strike-slip fault, the R structure forms at an early stage to become first-order shear structures. $\mathrm{R}^{\prime}$ structure is the conjugate shear structure of $\mathrm{R}$ structure, but in some case R' cannot be found (Tchalenko and Ambraseys 1970). $\mathrm{R}$ structures and tension fractures formed during the first stage, and then P structures formed (Rao et al. 2011). In natural shear zone systems, the angular relationships between individual shear features, especially R, R', and P structures, and the PDZ are affected by various factors, such as local geological conditions, strain rate, and stress state at the time of faulting (Ahlgren 2001; Lin and Nishikawa 2011).

The higher angle between Riedel shear geometries (R) and the principal shear zone developed within the $\mathrm{G}, \mathrm{K}, \mathrm{L}$, and $\mathrm{M}$ segments, and the lower-angle Riedel shears within the $\mathrm{H}, \mathrm{I}$, and $\mathrm{J}$ segments (Fig. 7) could reflect the nature of local geological structures in the unconsolidated alluvial deposits and the basement rocks during co-seismic rupture formation. It is also affected by the original topography and existing structures. For example, the G, K, L, and M segments are mainly composed of conglomerate, while the $\mathrm{H}$ and I segments located on the Hualien Formation consist of sand and mud sediments (Fig. 2d; Chung et al. 2004).

The tension fractures can be interpreted as new surface ruptures that develop mainly within unconsolidated alluvial deposits during the early stages of fault evolution (Tchalenko 1970; Tchalenko and Ambraseys 1970). According to lab experiments, the tension fractures indicating maximum principal stress $\left(\sigma_{1}\right)$ within the PDZ are inclined at $45 \pm 5^{\circ}$ to the principal shear direction initially, regardless of the lithology and local stress state (Bartlett et al. 1981).

However, through the comprehensive analysis of each shear feature in this study, we found not only the R and R' structures, but also the compressed textures and the tension fractures with a large amount of measurement data to reduce the impact of the factors. We believe that the analysis of the co-seismic surface ruptures can accurately reflect the nature of the Milun Fault.

\subsection{Surface Deformation Versus Surface Rupture Investigation}

Based on the DInSAR (Differential Interferometric SAR) result of the 2018 Hualien Earthquake using the Sentinel satellite descending images (20180205 - 20180211, Fig. 8; Hsu et al. 2018), ground deformation can be clearly observed. In the interferogram, each fringe represents a variation of $2.8 \mathrm{~cm}$ in the line-of-sight (LOS), and the tighter of fringe reflect the larger the deformation gradient. The discontinuous fringes cut by the Milun Fault indicate the occurrence of the surface displacement occurring along the Milun Fault. The hanging wall of the Milun Fault is clearly shortened displacement along LOS. The surface deformation on the south-west side of the Milun Fault (close to the Central Range) can also be clearly observed.

Upon comparing the DInSAR results with our observation (Fig. 8), it can be seen that the fringes discontinuities are consistent with the direction of the local PDZ mentioned before. In Qixingtan area, there is an abrupt phase change boundary, the direction of which is close to the east-west direction (Fig. 8b). Near the Meilun campus of NDHU and the central part of Meilun Hill, we can observe the turning point of the interferometric fringes. The azimuth of discontinuous direction is close to $170^{\circ}$ (Figs. 8c, d), which is similar to the fault branches proposed in this study. However, in the southern part of the Milun Fault, the ground displacement is more complicated and the boundary of fringe discontinuities is not obvious.

\subsection{Complexity and Explanation of the Co-seismic Surface Rupture}

When analyzing the Riedel shear of the co-seismic rupture (outcrops scale), it reflected the local PDZ and principal local stresses $\left(L \sigma_{1}\right)$. These Riedel shear structures are marked by classic R-shears, R'-shear, tension fracture, and $P$ structure, but these elements are not fully developed in every segment. In addition, the outcrop-scale Riedel shear zone shows 4 sets of local PDZs (Fig. 7). Therefore, it is necessary to integrate these local PDZs, and detailed structural mapping to better understand the significance of this deformation in regional scale.

Based on Riedel shear structure theory, we observe the Milun Fault, the adjacent fault and local PDZs (Fig. 7) from the macro-scale. We illustrate the local PDZ of each segment on the map, and then use the angular relationship to correspond to the elements of the Riedel shear structure (Fig. 9a). In the macro-scale result, the regional PDZ direction is azimuth $5^{\circ}$ (segment $\mathrm{J}, \mathrm{L}, \mathrm{M}$ ); the local PDZ in segment $\mathrm{K}$ and $\mathrm{J}$ correspond to $\mathrm{R}$ structure (azimuth $170^{\circ}$ ), and the north part of the Milun Fault correspond to P structure (segment $\mathrm{H}$ and $\mathrm{I}-1$, azimuth $25^{\circ}$ ). In addition, with the observation of small-scale right-lateral strike-slip fractures (azimuth $110^{\circ}$ ), tensile fractures (azimuth $140^{\circ}$ ) and compression textures (azimuth $50^{\circ}$ ), they can be combined into a perfect Riedel shear model (Fig. 9b), and indicating that the direction of maximum horizontal compress stress $\left(\sigma_{\mathrm{H} \max }\right)$ is NW-SE (azimuth $140^{\circ}$ ).

According to our field investigation results and macro-scale Riedel shear model analysis of the 2018 Hualien 


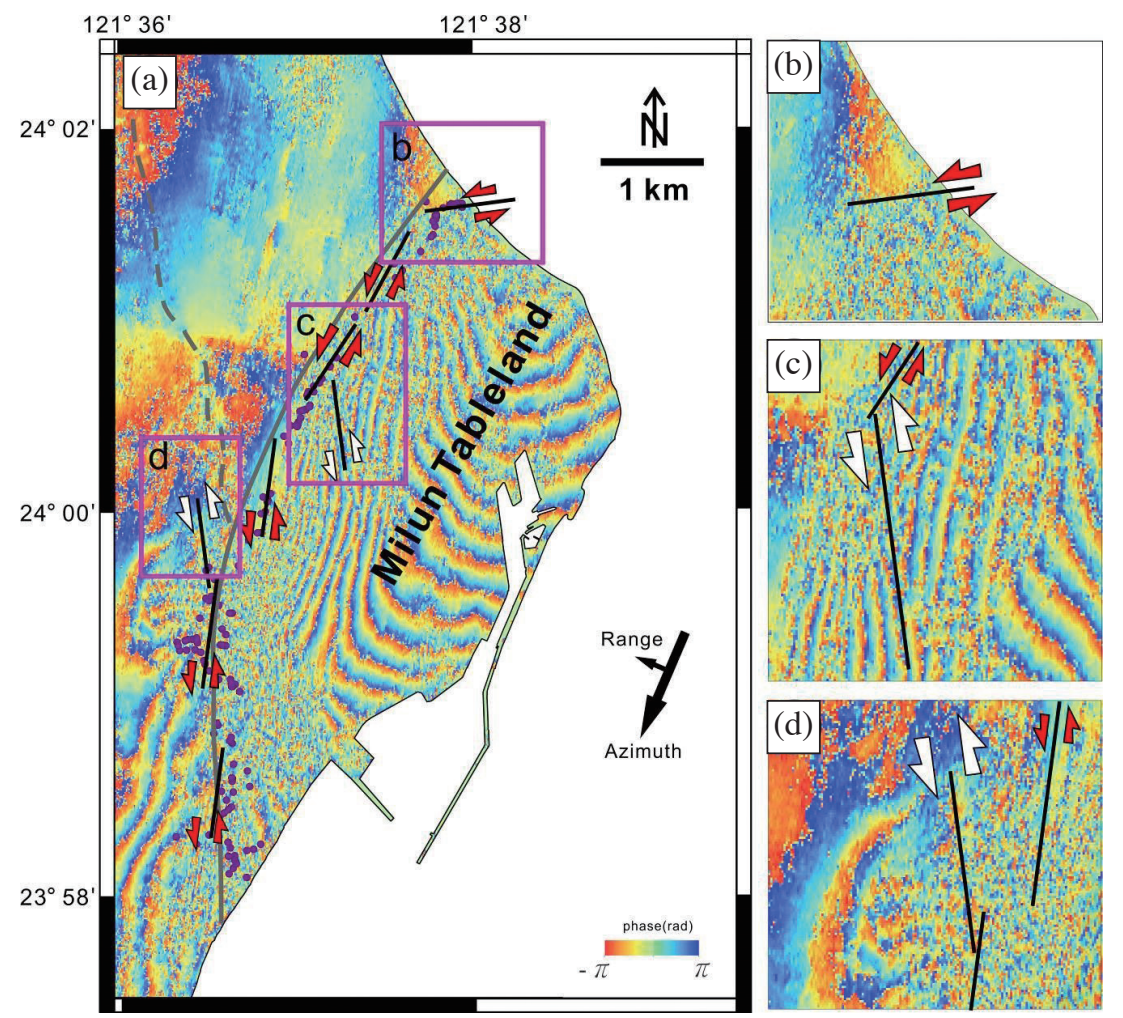

Fig. 8. (a) DInSAR results of the 2018 Hualien Earthquake using the Sentinel satellite descending images (20180205 - 20180211; Hsu et al. 2018). The purple points are the surface ruptures locations. The black lines and arrows are the principal shear zones from the results of this study. The gray line is the Milun Fault and the Beipu Fault. (b), (c), and (d) are the enlarged map of the DInSAR result. The position is indicated in (a).

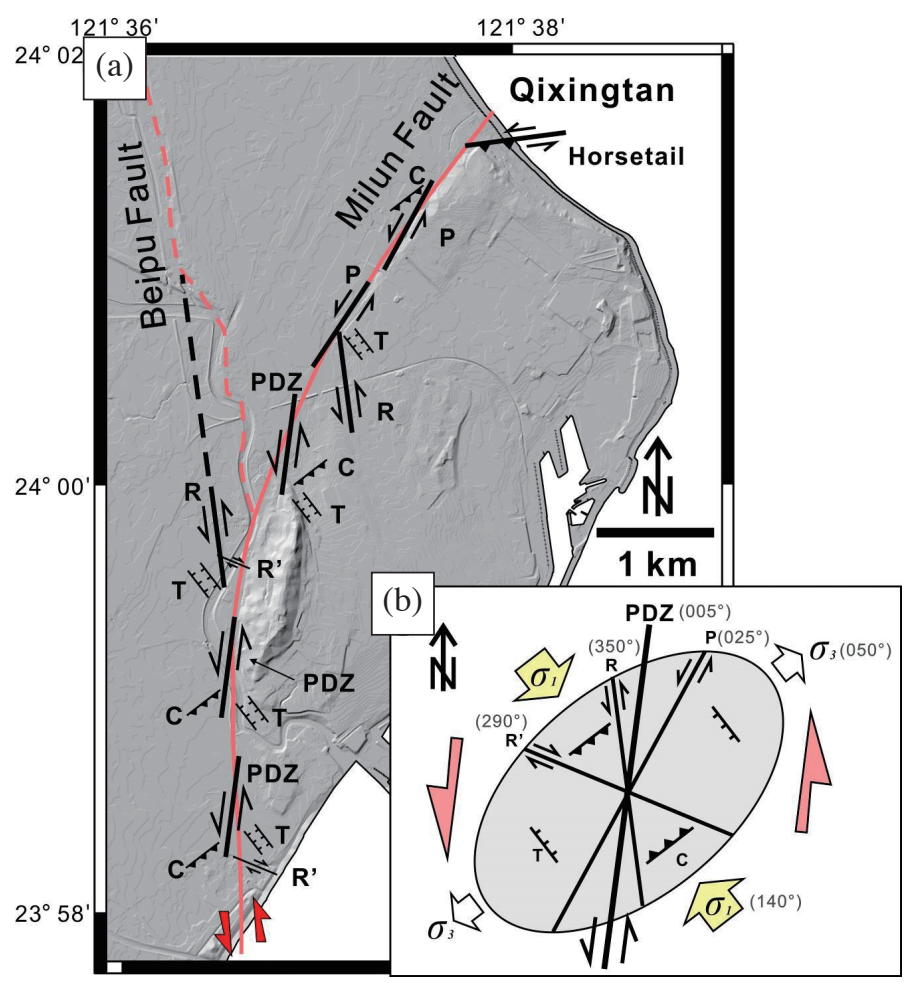

Fig. 9. Surface deformational active structural elements occurring in the Milun Fault during the 2018 Hualien Earthquake. (a) The principal shear direction of G - M segment and secondary structures pattern. The pink line is the Milun Fault and the Beipu Fault. (b) Plan view geometric relations between Riedel shear structures in this study. PDZ: principal displacement zone; R: R structure; R': R' structure; P: P structure; T: tension fracture; C: compression texture. 
Earthquake, there is a special feature that needs to be discussed-the E-W trending PDZ of the Qixingtan area (Fig. 7). In the strike-slip fault growth process, some horsetail splays or smaller fault splays are very common. Typically, fault splays comprising of the horsetail are curved-type. Depending on the direction of the curvature with respect to the sense of displacement, a reverse fault system or a normal fault system occurs in the faults of the horsetail. These movements will be accompanied by either folding or uplift, where there is a thrust component, or tilting and subsidence, where there is a normal component (Van der Pluijm and Marshak 2003).

In Qixingtan area, the orientation of the PDZ of the Milun Fault shows a change of more than 50 degrees. Since the Qixingtan area is at the northern end of the Milun Fault, the compression of the area during the earthquake is very significant. It is possible that the PDZ here is a horsetail splay derived from the right side of the end of the left-lateral strike-slip fault, instead of the northern extent of the preexisting Milun Fault.

Furthermore, it is noteworthy that the orientation of the two $170^{\circ}$ trending fault branches is very similar to the Beipu Fault. The Beipu Fault developed along the western side of the Meilun Hills. During the 2005 earthquake event, a significant uplift occurred, which was observed through DInSAR analysis (Chang et al. 2006; Yen et al. 2011). Chang et al. (2006) proposed that the Beipu Fault is the frontal part of the Milun Fault, which propagates towards the west with a counter-clockwise rotation. After the 2018 Hualien Earthquake, we also observed slight deformation along the Beipu Fault, which reveals that the Beipu Fault continues to be active and is not yet coupled (Fig. 8d; Hsu et al. 2018). Based on macroscopic Riedel shear structural analysis, we suggest that the Beipu Faults is also the R structures in the Riedel shear model developed corresponding to the left-lateral fault system of the Milun Fault (Fig. 9).

\subsection{Kinematics of the Milun Fault}

The Milun Fault is located at the northern tip of the Longitudinal Valley, which is the active structure between the Philippine Sea plate and the Eurasian plate (Chen et al. 2014a). Several previous studies suggest that the Milun Fault is an active fault. For the 1951 Hualien earthquake, it has been considered as the seismogenic fault (Hsu 1955). However, in most cases, the activity of the Milun Fault is controlled by the surrounding earthquake. When a large earthquake occurs in the adjacent areas, a clear displacement, including both the horizontal and vertical components along the Milun Fault, can often be observed (Yu et al. 1990; Yen et al. 2011). Relatively slow horizontal displacement has also been reported during the inter-seismic period (e.g., 3 - $8 \mathrm{~mm} \mathrm{y}^{-1}$; Chen et al. 2014a). For the 2018 Hualien Earthquake, the Milun Fault is not the seismogenic fault. However, a co-seismic displace- ment of approximately 20 and $15 \mathrm{~cm}$ for its left-lateral strikeslip and vertical components, respectively, has been clearly observed along it. In addition, the largest horizontal displacement of $70 \mathrm{~cm}$ and the largest vertical displacement of nearly $50 \mathrm{~cm}$ occurred in the northern end of the horsetail splay, in the Qixingtan area.

The main shock from the 2018 Hualien Earthquake is affected by a compressional stress in the NNW-SSE direction (Fig. 7b), and the $\mathrm{P}$ axis from the focal mechanism of the background earthquake shows NW-SE compression, it means that the earthquake was mainly affected by the Philippine Sea plate to the northwest. Through the macroscopic Riedel shear structural analysis, show that the main maximum horizontal compression stress $\left(\sigma_{\mathrm{Hmax}}\right)$ direction causing damage in the study area is NW-SE (Fig. 9b). This result is similar to the background stress. However, the trajectory of the stress field can be a slight rotation in local Riedel shear zone. In the general case, the maximum principal local stresses $\left(L \sigma_{1}\right)$ as inverted from the orientations of the conjugate structures ( $\mathrm{R}$ and $\mathrm{R}$ ') for each set of Riedel shear zone. The obliquity of $\mathrm{R}$ and $\mathrm{R}$ ' orientations are causes stress rotation from regional to local, for each set of Riedel shear zones (Segall and Pollard 1980; Mandl 1988; Davis et al. 2000). The maximum horizontal compression stress $\left(\sigma_{\text {Hmax }}\right)$ directions of each segment $(\mathrm{G}-\mathrm{M}$ block) are shown in Fig. 7. This result shows that the $\sigma_{\mathrm{Hmax}}$ rotated to the NE-SW direction in the Qixingtan area, and the NE-SW direction of the $\sigma_{\mathrm{H} \max }$ on the $170^{\circ}$ trending fault.

\section{CONCLUSIONS}

Based on the investigation and analysis of the co-seismic surface rupture produced by the 2018 Hualien Earthquake on the Milun Fault, we have reached the following conclusions:

(1) The co-seismic surface ruptures of the 2018 Hualien Earthquake consist of Riesel shear structures, including the $\mathrm{R}$ and $\mathrm{R}$ ' conjugate shear fractures, en echelon tension cracks, tension fractures, and compression textures. By analyzing the co-seismic surface rupture patterns, we can identify the principal displacement zones and the orientation of the maximum compressive stresses.

(2) Based on the analysis, the principal shearing direction rotates in the anti-clockwise direction along the Milun Fault. The principal shearing direction in the Qixingtan area is close to the E-W trend (azimuth $80^{\circ}$ ), although it gradually turns to the NE-SW trend in the west. To the south of the Meilun Hill area, the principal shearing direction changes to the N-S direction.

(3) According to the fracture deformation behavior and the relative position of the Milun Faults, it can be understood that the Milun Fault forms a horsetail structure in the northernmost area of Qixingtan, along with the fault splays of azimuth of $170^{\circ}$ in the central segments. 
(4) Combining the results of DInSAR and co-seismic surface ruptures analysis, we believe that the principal shear direction and the shear sense results have a certain degree of credibility.

(5) Through the macroscopic Riedel shear structural analysis, the Milun Fault develop along N-S direction (PDZ), the Beipu Fault and $170^{\circ}$-oriented faults are the R structures and NE-strike fault in the north segment of Milun Fault is P structure. This Riedel shear model indicates that the direction of maximum horizontal compress stress $\left(\sigma_{\text {Hmax }}\right)$ is NW-SE.

(6) This study provides a good example of understanding the relationship between the outcrop scale and the macro-scale of the Riedel shear model.

Our results show that Riedel shear structures are common within co-seismic surface rupture zones, and the variations in the orientations of Riedel structural elements reflect the influence of the pre-existing Milun Fault.

Acknowledgements This article is grateful to the team of the Eastern Taiwan Earthquake Research Center and the Department of Natural Resources and Environmental Sciences of the National Dong Hwa University for conducting detailed surface rupture investigations in Hualien County after the earthquake. We also thank to the Center for Space and Remote Sensing Research in National Central University for providing high-resolution SPOT7 images, allowing us to perform large-area surface observations through optical satellite imagery. This research was also supported by the Ministry of Science and Technology of Taiwan (MOST 104-2628-M-008-005-MY3).

\section{REFERENCES}

Ahlgren, S. G., 2001: The nucleation and evolution of Riedel shear zones as deformation bands in porous sandstone. J. Struct. Geol., 23, 1203-1214, doi: 10.1016/ S0191-8141(00)00183-8. [Link]

Angelier, J. and F. Bergerat, 2002: Behaviour of a rupture of the 21 June 2000 earthquake in South Iceland as revealed in an asphalted car park. J. Struct. Geol., 24, 1925-1936, doi: 10.1016/S0191-8141(02)00007-X. [Link]

Bartlett, W. L., M. Friedman, and J. M. Logan, 1981: Experimental folding and faulting of rocks under confining pressure Part IX. Wrench faults in limestone layers.Tectonophysics, 79, 255-277, doi: 10.1016/00401951(81)90116-5. [Link]

Bestmann, M., K. Kunze, and A. Matthews, 2000: Evolution of a calcite marble shear zone complex on Thassos Island, Greece: Microstructural and textural fabrics and their kinematic significance. J. Struct. Geol., 22, 17891807, doi: 10.1016/S0191-8141(00)00112-7. [Link]

Chang, C. P., K. S. Chen, L. H. Chung, J. Y. Yen, and T. S. Shih, 2006: Active fault propagation in metropolitan
Hualien of eastern Taiwan: Observed by radar interferometry and field investigation. International Workshop: Applications of SAR Data in Taiwan, Taoyuan, Taiwan.

Chang, K. J., J. B. H. Shyu, Y. C. Chan, R. F. Chen, and E. C. Yen, 2014a: Near fault active deformation and morphotectonic analysis based on high-resolution Airborne LiDAR data (4/4). Central Geological Survey, MOEA Investigation Report, 260 pp. (in Chinese)

Chang, K. J., J. B. H. Shyu, Y. C. Chan, R. F. Chen, and E. C. Yen, 2014b: Near fault active deformation and morphotectonic analysis based on high-resolution Airborne LiDAR data (General report). Central Geological Survey, MOEA Investigation Report, 329 pp. (in Chinese)

Chen, C. Y., J. C. Lee, Y. G. Chen, and R. F. Chen, 2014a: Campaigned GPS on Present-Day Crustal Deformation in Northernmost Longitudinal Valley Preliminary Results, Hualien Taiwan. Terr. Atmos. Ocean. Sci., 25, 337-357, doi: 10.3319/TAO.2013.12.25.01(TT). [Link]

Chen, S. K., Y. C. Chan, J. C. Hu, and L. C. Kuo, 2014b: Current crustal deformation at the junction of collision to subduction around the Hualien area, Taiwan. Tectonophysics, 617, 58-78, doi: 10.1016/j.tecto.2014.01.014. [Link]

Chen, W. S., I. C. Yen, K. P. Fengler, C. M. Rubin, C. C. Yang, H. C. Yang, H. C. Chang, C. W. Lin, W. H. Lin, Y. C. Liu, and Y. H. Lin, 2007: Late Holocene paleoearthquake activity in the middle part of the Longitudinal Valley fault, eastern Taiwan. Earth Planet. Sci. Lett., 264, 420-437, doi: 10.1016/j.eps1.2007.09.043. [Link]

Chung L. H., T. S. Shi, Y. Q. Liu, W. L. Hsu, C. M. Shih, and W. C. Wu, 2004: Active Fault Investigation Report - Milun Fault. Ministry of Economics Central Geological Survey Policy Plan, Central Geological Survey, MOEA Investigation Report, 17 pp. (in Chinese)

Davis, G. H., A. P. Bump, P. E. García, and S. G. Ahlgren, 2000: Conjugate Riedel deformation band shear zones. J. Struct. Geol., 22, 169-190, doi: 10.1016/S01918141(99)00140-6. [Link]

Hsu, T. L., 1955: The earthquakes of Taiwan. Quart. J. Bank Taiwan, 7, 148-164. (in Chinese)

Hsu, T. L., 1962: Recent faulting in the Longitudinal Valley of eastern Taiwan. Mem. Geol. Soc. China, 1, 95-102.

Hsu, Y. C., J. Y. Yen, C. H. Lu, C. C. Wang, B. L. Wu, Y. H. Chang, W. Y. Chang, C. P. Chang, and H. Kuo-Chen, 2018: Investigating Surface Ruptures and Co-Seismic Deformation of 0206 Hualien Earthquake Using Field Survey and Remote Sensing. Sino-Geotechnics, 156, 15-24. (in Chinese)

Kao, Y. H., 2016: Faults Activities and Crustal Deformation of Hualien City Analysed by geodetic measurements 
and Geophysical Prospecting. Master Thesis, National Dong Hwa University, Hualien, Taiwan, 104 pp. (in Chinese)

Katz, Y., R. Weinberger, and A. Aydin, 2004: Geometry and kinematic evolution of Riedel shear structures, Capitol Reef National Park, Utah. J. Struct. Geol., 26, 491-501, doi: 10.1016/j.jsg.2003.08.003. [Link]

King, G. C. P., 1986: Speculations on the geometry of the initiation and termination processes of earthquake rupture and its relation to morphology and geological structure. Pure Appl. Geophys., 124, 567-585, doi: 10.1007/BF00877216. [Link]

Liau, H. S., 2006: Shallow seismic reflection survey of the Milun Fault. Master Thesis, National Chung Cheng University, Chiayi, Taiwan, 82 pp. (in Chinese)

Lin, A. and M. Nishikawa, 2011: Riedel shear structures in the co-seismic surface rupture zone produced by the $2001 \mathrm{M}_{\mathrm{w}} 7.8$ Kunlun earthquake, northern Tibetan plateau. J. Struct. Geol., 33, 1302-1311, doi: 10.1016/j. jsg.2011.07.003. [Link]

Lin, A., T. Ouchi, A. Chen, and T. Maruyama, 2001: Coseismic displacements, folding and shortening structures along the Chelungpu surface rupture zone occurred during the 1999 Chi-Chi (Taiwan) earthquake. Tectonophysics, 330, 225-244, doi: 10.1016/S00401951(00)00230-4. [Link]

Lin, A., M. Kikuchi, and B. Fu, 2003: Rupture segmentation and process of the $2001 M_{\mathrm{w}} 7.8$ central Kunlun, China, earthquake. Bull. Seismol. Soc. Am., 93, 2477-2492, doi: 10.1785/0120020179. [Link]

Lin, A., Z. Ren, D. Jia, and X. Wu, 2009a: Co-seismic thrusting rupture and slip distribution produced by the 2008 $M_{\mathrm{w}} 7.9$ Wenchuan earthquake, China. Tectonophysics, 471, 203-215, doi: 10.1016/j.tecto.2009.02.014. [Link]

Lin, A., G. Rao, D. Jia, X. Wu, B. Yan, and Z. Ren, 2011: Co-seismic strike-slip surface rupture and displacement produced by the $2010 \mathrm{M}_{\mathrm{W}} 6.9$ Yushu earthquake, China, and implications for Tibetan tectonics. J. Geodyn., 52, 249-259, doi: 10.1016/j.jog.2011.01.001. [Link]

Lin, C. C., 1962: The Quaternary of the Hualien area - the Quaternary of Taiwan. National Council on Science Development Research Report, 42 pp. (in Chinese)

Lin, C. W., W. S. Chen, Y. C. Liu, and P. T. Chen, 2009b: Active faults of eastern and southern Taiwan: Explanatory text for the strip maps of active faults scale 1:25,000. Central Geological Survey Special Publication, Vol. 23, 178 pp. (in Chinese)

Lin, M. S. and C. L. Hsiao, 1998: The strike-slip fault system in the Milun Tableland. Res. of Eastern Taiwan, 3, 13-30. (in Chinese)

Lu, C. H., 2009: Faults Activities and Crustal Deformation near Hualien City, eastern Taiwan Analysed by Persistent Scatterer InSAR. Master Thesis, University of
Taipei, Taipei, Taiwan, 82 pp. (in Chinese)

Mandl, G., 1988: Mechanics of Tectonic Faulting: Models and Basic Concepts, Elsevier, Amsterdam, 407 pp.

Rao, G., A. Lin, B. Yan, D. Jia, X. Wu, and Z. Ren, 2011: Co-seismic Riedel shear structures produced by the $2010 \mathrm{M}_{\mathrm{w}} 6.9$ Yushu earthquake, central Tibetan Plateau, China. Tectonophysics, 507, 86-94, doi: 10.1016/j. tecto.2011.05.011. [Link]

Riedel, W., 1929: Zur Mechanik Geologischer Brucherscheinungen. Centralblatt fur Minerologie, Geologie, und Paleontologie, B, 354-368.

Scholz, C. H., R. Ando, and B. E. Shaw, 2010: The mechanics of first order splay faulting: The strike-slip case. J. Struct. Geol., 32, 118-126, doi: 10.1016/j. jsg.2009.10.007. [Link]

Segall, P. and D. D. Pollard, 1980: Mechanics of discontinuous faults. J. Geophys. Res., 85, 4337-4350, doi: 10.1029/jb085ib08p043371. [Link]

Shih, T. T., J. C. Chang, C. E. Hwang, C. D. Shih, and G. S. Yang, 1983: A geomorphological study of active fault in northern and eastern Taiwan. Geographical Research, 9, 20-72. (in Chinese)

Tchalenko, J. S., 1968: The evolution of kink-bands and the development of compression textures in sheared clays. Tectonophysics, 6, 159-174, doi: 10.1016/00401951(68)90017-6. [Link]

Tchalenko, J. S., 1970: Similarities between shear zones of different magnitudes. Geol. Soc. Am. Bull., 81, 16251640, doi: 10.1130/0016-7606(1970)81[1625:SBSZO D]2.0.CO;2. [Link]

Tchalenko, J. S. and N. N. Ambraseys, 1970: Structural analysis of the Dasht-e Bayaz (Iran) earthquake fractures. Geol. Soc. Am. Bull., 81, 41-60, doi: 10.1130/0016-7606(1970)81[41:SAOTDB]2.0.CO;2. [Link]

Tang, W. B., 1952: Earthquake Report 1951, Taiwan Weather Bureau, Taipei, 83 pp. (in Chinese)

Van der Pluijm, B. A. and S. Marshak, 2003: Earth Structure: An Introduction to Structural Geology and Tectonics, Second Edition, W. W. Norton \& Company, $672 \mathrm{pp}$.

Wu, Y. M., J. B. H. Shyu, C. H. Chang, L. Zhao, M. Nakamura, and S. K. Hsu, 2009: Improved seismic tomography offshore northeastern Taiwan: Implications for subduction and collision processes between Taiwan and the southernmost Ryukyu. Geophys. J. Int., 178, 1042-1054, doi: 10.1111/j.1365-246X.2009.04180.x. [Link]

Yang, G. S., 1986: A geomorphological study of active faults in Taiwan-especially on the relation between active faults and geomorphic surfaces. Ph.D. Thesis, Chinese Culture University, Taipei, Taiwan, 178 pp. (in Chinese)

Yen, J. Y., C. P. Chang, K. S. Chen, L. H. Chung, and T. S. 
Shih, 2006: Active fault propagation in metropolitan Hualien of eastern Taiwan: Observed by radar interferometry and field investigation. International Workshop: Applications of SAR Data in Taiwan, Taoyuan, Taiwan.

Yen, J. Y., C. H. Lu, C. P. Chang, A. J. Hooper, Y. H. Chang, W. T. Liang, T. Y. Chang, M. S. Lin, and K. S. Chen, 2011: Investigating active deformation in the northern Longitudinal Valley and City of Hualien in eastern Taiwan using persistent scatterer and small-baseline SAR interferometry. Terr. Atmos. Ocean. Sci., 22, 291-304, doi: 10.3319/TAO.2010.10.25.01(TT). [Link]

Yu, M. S., 1994: Wrench-fault characteristics of the Taitung Longitudinal Valley Fault zone. Ti-Chih, 14, 121-147. (in Chinese)

Yu, S. B. and L. C. Kuo, 2001: Present-day crustal motion along the Longitudinal Valley Fault, eastern Taiwan. Tectonophysics, 333, 199-217, doi: 10.1016/S00401951(00)00275-4. [Link]

Yu, S. B., D. D. Jackson, G. K. Yu, and C. C. Liu, 1990: Dislocation model for crustal deformation in the Longitudinal Valley area, Eastern Taiwan. Tectonophysics, 183, 97-109, doi: 10.1016/0040-1951(90)90190-J. [Link]

Yu, S. B., H. Y. Chen, and L. C. Kuo, 1997: Velocity field of GPS stations in the Taiwan area. Tectonophysics, 274, 41-59, doi: 10.1016/s0040-1951(96)00297-1. [Link]

Zhang, B., J. Zhang, and D. Zhong, 2010: Structure, kinematics and ages of transpression during strain-partitioning in the Chongshan shear zone, western Yunnan, China. J. Struct. Geol., 32, 445-463, doi: 10.1016/j. jsg.2010.02.001. [Link] 